\title{
LAND-USE CHANGES IN THE SPANISH PYRENEES
}

\author{
Jose M. Garcia-Ruiz and Teodoro Lasanta-Martinez \\ Instituto Pirenaico de Ecologia \\ Apartado 64 \\ Jaca (Huesca), Spain
}

\begin{abstract}
This paper discusses the evolution of land use in the Spanish Pyrenees and the environmental and demographic factors that led to change. The traditional system depended upon a complex social organization and abundant cheap labor; there was extensive summer grazing for sheep which in winter moved to the Ebro Basin; and, despite the unfavorable environment, the cultivation of cereals was important. In the second half of the twentieth century, outmigration led to a disruption of the management systems: transhumance disappeared and cattle replaced sheep; cultivated slopes have been abandoned while in the valley bottoms agriculture has been intensified; meadows have been converted to cereal production to ensure the supply of winter feed to livestock.
\end{abstract}

RÉSUmé Changements d'utilisation des terres dans les Pyrénées espagnoles. Cet article examine l'évolution de l'utilisation des terres dans les Pyrénées espagnoles, ainsi que les facteurs environnementaux et démographiques qui ont provoqué ces changements. Le système traditionnel reposait sur un régime social complexe ainsi qu'une main-d'oeuvre abondante et bon marché. Il était caractérisé par un pâturage extensif des moutons en été, et par un repli vers le bassin de l'Ebro en hiver. En dépit des conditions défavorables, la culture des céréales était importante. Au cours de la seconde moitié du vingtième siècle, l'émigration a provoqué une perturbation des systèmes de gestion: la transhumance a disparu et les bovins ont remplacé les moutons; les pentes cultivées ont été abandonnées alors que l'agriculture a été intensifiée dans les vallées; les pâturages ont été convertis à la culture de céréales pour assurer l'alimentation du bétail en hiver.

ZUSAMmEnfassung Veränderunger bei der Landnutzung in den spanischen Pyrenäen. Diese Veröffentlichung diskutiert die Entwicklung der Landnutzung in den spanischen Pyrenäen, sowie solche Umwelt- und demographischen Faktoren, die zu Veränderungen führten. Das traditionelle System stützte sich auf eine komplexe, soziale Gemeinschaft mit vielen billigen Arbeitskräften; für Schafherden gab es ausreichendes Sommerweideland, im Winter wurden sie ins Ebro Becken abgetrieben; und trotz widriger Umweltbedingungen war auch Getreideanbau wichtig. In der zweiten Hälfte des 20. Jahrhunderts führte Abwanderung jedoch zu Störungen im Managementsystem: Die Schafwirtschaft verschwand und wurde durch Rinderzucht ersetzt; kultivierte Hänge lagen brach, währen in den Tälern die Landwirtschaft intensiviert wurde. Um die Viefutterversorgung für den Winter zu sichern, wurden Weidflächen zum Getreideanbau umgepflügt.

RESUMEN Cambios en la utilización del territorio en los Pirineos españoles. Se expone la evolución de los cultivos y utilización del territorio en el Pirineo español, además de las causas ambientales y los factores demográficos que han regido los referidos cambios. El sistema tradicional se apoyaba en una compleja organización social y acusada dedicación al pastoreo; tal última actividad se refería al aprovechamiento extensivo de las estivas de altitud preferentemente con ganado ovino y el descenso invernal a la depresión del Ebro; pese a lo desfavorable del entorno, en los valles altos, fué importante el cultivo de los cereales. En el transcurso de la segunda mitad del siglo XX, la emigración quebrantó el sistema gestor: desapareció la trashumancia y el vacuno reemplazó al ovino; las laderas labradas se abandonaron, mientras se intensificó la agricultura de los fondos de valle; los prados han sustituido la producción de cereal, intentando asegurar con excedentes de hierba, la sobrevivencia invernal del ganado.

\section{LAND-USE CHANGES IN THE SPANISH PYRENEES}

The mountainous regions of Europe have suffered profound changes during the last few decades, particularly those that are influenced by the development and expansion of neighboring urban centers. In the Spanish Pyrenees the changes have taken place later than in other regions but they were none-the-less intense.

Several authors reported on the social transformations that occurred during the $1950 \mathrm{~s}$ and especially in the $1960 \mathrm{~s}$ (Esteva-Fabregat, 1971; Daumas, 1976; Garcia-Ruiz,
1976; Garcia-Ruiz and Balcells, 1978; Anglada et al., 1980). Most of these case studies are regional in scope or treat one specific factor; in this paper we consider the mountain range as a system - one integrated by subsystems that constitute a very complex mosaic. In the past this system was well adapted to the local ecological conditions which resulted in the maintenance of a high population density. However, it has experienced different external stimuli that have caused internal reactions, and have 
resulted in changes in spatial organization, in land use, and in the capacity for production. At the present time some mountain areas are being used in a very intensive way with large investments and considerable inputs of energy, while other areas have been relegated to an extensive exploitation system, sometimes quite different from the traditional one; certain other areas have been completely abandoned.

These recent changes have important effects on the dynamics of the ecosystem. The factors involved in the changes that are external to the system have already been discussed (Esteva Fabregat, 1971; Garcia-Ruiz, 1976). In this paper we will present the traditional model of exploitation and then describe the new model of space organization and discuss the differences that exist throughout the Pyrenean range. Such differences may result from either the diversity of the mountain environment or the quality and intensity of external pressure.

\section{THE STUDY AREA}

Two outstanding features of the Pyrenees are lithological and tectonic diversity and the high energy of relief, which is responsible for the steep slopes and the deeply incised fluvial network. In the first case, granite, limestone, sandstone, flysch, slate, and schist produce very contrasting topography with differing slope angles and soil depths, and therefore different exploitation potential. Granite, limestone, and sandstone give rise to more pronounced and steep relief and a landscape suitable only for grazing or for forest. Flysch produces a very homogeneous relief with gently sloping watersheds facing southward, and regular slopes occupied by forest or abandoned croplands. Slates and schists generate undulating landscapes which generally are used only as pastures above timberline and which are subject to large mass movements.

In general, the lithographic structure shows a succession of parallel bands trending west-east. The fluvial network, in contrast, extends north-south across the structure. Glacial activity, particularly in the central sections, led to the widening of some valleys and the development of broad basins which are used as summer pastures in the higher areas and for agriculture lower down. In the major glacial troughs, side valleys filled with glacio-lacustrine sediments are used for agriculture. In the main valleys, post-glacial alluvial fans are fertile and are used for cultivation and sometimes as sites for settlements.

Two aspects of climate have important influence on spatial organization in the Spanish Pyrenees. On the one hand, there is a progressive transition from west to east from a mountain oceanic climate to a more Mediterranean one, with a region of continental climate in the Central Pyrenees (Creus, 1978; Del Barrio et al., this issue, 227-233). The humid influences coming from the Atlantic affect the Western Pyrenees, especially the northern slopes in winter, while the Central Pyrenees have a dry winter and humid spring and aridity again at the end of summer. On the other hand, the altitudinal factor causes important thermal and pluviometric contrasts. Low temperature restricts cultivation above $1,700 \mathrm{~m}$; the upper limit of natural forest is 2,100 $\mathrm{m}$; and above $1,600 \mathrm{~m}$ snow covers most of the ground from December to March-April and geomorphological phenomena related to freeze-thaw progressively become more dominant.

All these factors allow us to distinguish schematically three levels of land use (Garcia-Ruiz, 1988). A cultivation belt occurs in the lowest sections of the valley and some- times is localized on perched flats. Above this, there is a belt that is forested on shady slopes but where the sunny slopes have been highly affected by nomadic cultivation as a result of strong demograhic pressure (Garcia-Ruiz, 1976). Finally, over $1,500-1,700 \mathrm{~m}$ is a belt above the forest pastures that is used in summer for the grazing of animals. The induced lowering of the upper forest limit by human activities is common in other mountainous regions throughout the world (Millones, 1982). It results from the need to expand the pastures in order to keep more livestock and also to extend the period of time in which pastures are used, due to the incapacity of domestic cattle to adapt to very high-altitude ecosystems.

Most of the land above timberline is exploited under communal systems, although the management is mainly controlled by state institutions. In the valleys of the Central Pyrenees, over 90 percent of the land is communal (in Anso, 94.5\% ; Broto, 98.6\%; and Benasque, 97.3\%). This indicates the reduced dependency of the Pyrenean people on private resources and the importance of communal ones which has led to the establishment of very complicated rules of land use (Kruger, 1929; Violant, 1949). The significance of individual agricultural property ownership in the Pyrenean valleys is minimal.

Finally, this environmental diversity of mountains and high density of population justified a very complex social organization based on large hierarchical structures (Esteva-Fabregat, 1971; Pujadas and Comas, 1975). The primogeniture system of heredity has contributed to the stability of the production unit and has ensured the existence of abundant and very cheap supplies of labor. Population decrease has dismantled the traditional social organization that was necessary for a particular form of exploitation; consequently, there has been an adjustment to much more simple land-use systems. It must be remembered that most villages lost more than half their population at the beginning of this century and some lost more than 60 percent.

Demographic recession seems to be less pronounced in the Western Pyrenees (Navarra) and it is hardly noticeable in those villages that are close to winter resorts (Sallent de Gallego). Loss of population reaches its maximum in the areas of traditional stock raising and also in locations far away from the main communication centers. Daumas (1986) points out that the villages in the bottom of the Benasque valley have suffered a population loss of 22 per- 
cent since 1940, while villages on the slopes have lost 51 percent. Figure 1 shows the demographic evolution of several Pyrenean townships.

At the same time there has been a notable tendency to aging: 25 percent of the population of many villages is over 65 years of age. Only the areas with important tourist impact have some population under 16 years, while townships based on stock raising have suffered noticeable changes in social structure. The primary sector is still dominant and comprises more than 60 percent of the active population of some villages (Fago; Hoz de Jaca; Plan); in some town- ships there is still a secondary sector related to forest exploitation (Anso; Benasque; Hecho); and in others the tertiary sector is of major importance (Hecho; Sallent; Panticosa; Torla; Benasque).

It is clear that both the demographic structure and the number of inhabitants have undergone substantial changes. At the same time, there have been adjustments in the economic conditions and in systems of transport; these have affected the relationship between the mountain region and the neighboring areas. The result has been massive changes in space organization and in land use.

\section{EXPLOITATION OF RESOURCES UNDER THE TRADITIONAL SYSTEM}

Figure 2 shows the pattern of land use in a Pyrenean valley. It is an example, a simplified version to allow easy interpretation of a system that is in fact very complex.

In general terms, four areas with different environmental features and uses can be distinguished. Forest pastures predominate at altitudes higher than $1,600 \mathrm{~m}$ and extend across the main divides of the major valleys and also across the lateral divides. The contact line with the forest is very

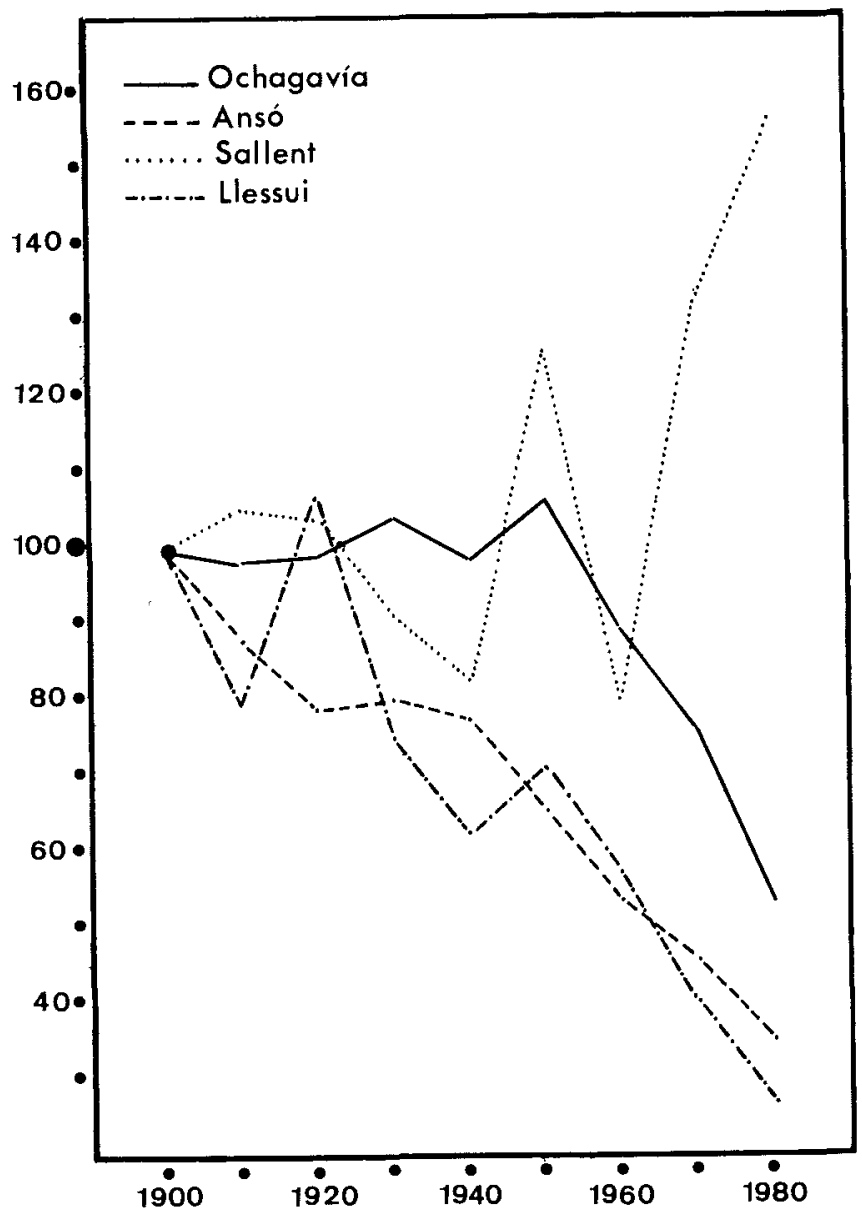

Figure 1. Percentage change in population in four Pyrenean villages between 1900 and 1980 . precise, although it follows an irregular pattern which is a function of topography, exposure, and human exploitation. The extent of forest varies widely from valley to valley; where population pressure has been very intense, forest is limited to shaded or very steep slopes, as in the Canfranc Valley. Generally, forest is more frequently found in the middle section of the valley while the lowest areas have been cleared.

Nevertheless, good expanses of pine can be found on some shaded lower slopes where they display an irregular distribution, as shown in Figure 2. Within the forest boundaries there are often small clearings where the soil is

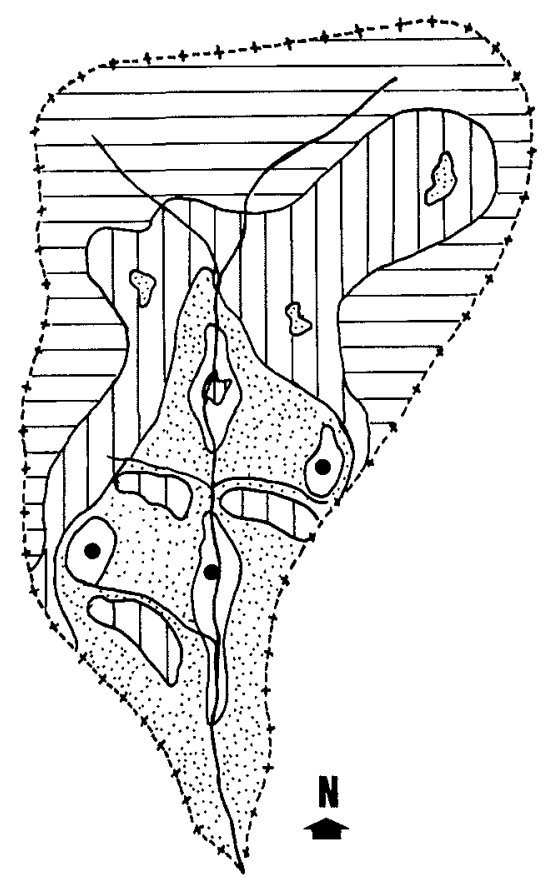

Cultivated land

Summer pastures and subalpine level

Abandoned fields and bushes

- Villages

Forests

Figure 2. The pattern of land use in Pyrenean village. 
deeper and rye and potatoes may be cultivated. These clearings are more frequently found in the Western Pyrenees where human impact is greater than in the Eastern mountains.

Elsewhere the landscape is being affected strongly by human activities. Valley floors have been intensively cultivated wherever they are not too narrow.

The main settlements are in flat valley bottoms where communication is easier and, above all, where there is agricultural land. Other, very small settlements are located 150-300 $\mathrm{m}$ above the main river bed, such as on perched flats, pre-Quaternary terraces, and moraines. Examples included the Tena (Gallego River), Broto, and Benasque valleys.

In the Western Pyrenees, significant areas were covered with brush, as a result of a type of shifting agriculture (articas), on steep, sunny slopes where there were no permanent structures (Kruger, 1939; Garcia-Ruiz, 1976). The articas are relegated to a very secondary role in the Central and Eastern Pyrenees. On the lower slopes, stonewalled terraces were built on steep gradients in order to increase the area under permanent cultivation and to protect the ground against torrential precipitation, which is increasingly more frequent towards the east. Water diversions were also built in order to prevent soil runoff, because cereal cultivation in the mountains involves a high risk of erosion (Puigdefabregas and Fillat, 1986).

This generalized scheme is complicated by the landscape diversity and consequently its wide range of production potential. Moreover, sometimes the agriculture is extended to the level of pastures above timberline by way of sunny flats where fodder and rye are grown in cycles of thirteen months. These lands (panares), mainly in the Central Pyrenees and at altitudes over $1,600 \mathrm{~m}$, have already been described by Daumas (1976); Puigdefabregas and Balcells (1970) found similar examples in the Western Pyrenees. The area of cultivation is quite large in most of the valleys. An analysis of air photographs dating from 1956 allows an estimate of the area under cultivation in different valleys and a comparison with the percentage of agricultural land in 1900 before the period of land abandonment, and also with present-day land use. The results are tabulated in Table 1. In order to avoid distortions caused by high massifs of uncultivable land in some townships, the percentages of the maximum cultivated surface in relation to other areas situated below $1,600 \mathrm{~m}$ is also given. This figure is about 30 percent for most valleys, which must be an underestimation because many old plots have been revegetated by natural growth and could not be counted as abandoned lands. These figures approximate those estimated by Garcia-Ruiz et al. (1985) in the Iberian system.

Some areas of forest (generally of Quercus faginea) were conserved near many of the villages. Oak, elm, ash, and more rarely birch trees were also conserved along pathways and field borders to retard soil creep and to provide leaves that could be used as fodder reserves in winter. This practice is still maintained today in some valleys of the Central Pyrenees (Gomez and Fillat, 1984).

Two regions beyond the Pyrenean range that are closely
TABLE 1

The area of cultivated land in selected Pyrenean valleys expressed as a percentage of a) total surface area and b) area below $1,600 \mathrm{~m}$ elevation.

\begin{tabular}{lrrr}
\hline \hline Valley & 1900 & 1957 & 1981 \\
\hline $\begin{array}{l}\text { Hecho } \\
\text { a) }\end{array}$ & 25.18 & 7.31 & 5.41 \\
b) & 30.18 & 8.58 & 6.48 \\
Aragüés & & & \\
a) & 15.50 & 4.45 & 2.92 \\
b) & 22.10 & 6.34 & 4.16 \\
Aisa & & & \\
a) & 19.02 & 7.42 & 4.97 \\
b) & 32.80 & 12.79 & 8.56 \\
Tena & & & \\
a) & 5.66 & 4.08 & 2.75 \\
b) & 27.70 & 19.99 & 13.48 \\
Biescas-Yésero & & & \\
a) & 19.93 & 10.73 & 8.65 \\
b) & 24.39 & 13.13 & 10.59 \\
Broto & & & \\
a) & 14.81 & 5.74 & 4.57 \\
b) & 30.86 & 11.96 & 9.51 \\
Bestúc-Puértolas & & & \\
a) & 18.87 & 6.12 & 2.98 \\
b) & 26.09 & 8.46 & 4.12 \\
\hline
\end{tabular}

related to production in the valley are the Prepyrenees and the Ebro Basin. The first is a sub-Mediterranean environment on the southern edge of the Pyrenees, characterized by small villages and large private landholdings. The forests (Pinus nigra, $P$. sylvestris, and Quercus faginea) have been cleared for extensive pastures (Garcia-Ruiz, 1976). The Ebro Basin, some 70-100 km south of the Pyrenean valleys, consists of level plains with a Mediterranean climate influenced slightly by continentality; they are quite arid with less than $400 \mathrm{~mm}$ of precipitation a year.

For a complete understanding of how a Pyrenean valley functions, the importance of pastures above timberline, both in absolute terms and in relation to agricultural land, must be taken into account. This is well indicated in Table 2 which gives the percentages of land under pasture and other uses in nine townships. Sheep readily adapt to pasture on steep gradients and play the dominant role in the traditional Pyrenean economy. Sheep and wool production were favored above cattle until the middle of this century. However, although the pastures are highly productive in summer, from October onwards grazing is limited to forests at lower elevations and degraded brushwoods; these can support only a small proportion of the sheep; the rough brush also reduces the quality of the wool.

Agricultural land that in a system based on sheep herding should be used to provide winter fodder is not available here. Competition between cultivation and husbandry in a mountainous environment develops for several reasons. First, food supplies for the people rather than for livestock are the priority. Data from several Pyrenean valleys since 
TABLE 2

Area of land under various uses in nine Pyrenean townships in 1984

\begin{tabular}{|c|c|c|c|c|c|c|c|c|c|c|c|c|c|c|c|c|c|c|}
\hline & \multicolumn{2}{|c|}{ Anso } & \multicolumn{2}{|c|}{ Hecho } & \multicolumn{2}{|c|}{ Tena } & \multicolumn{2}{|c|}{ Broto } & \multicolumn{2}{|c|}{ Plan } & \multicolumn{2}{|c|}{ Benasque } & \multicolumn{2}{|c|}{ Esteribar } & \multicolumn{2}{|c|}{ Aezcoa } & \multicolumn{2}{|c|}{ Salazar } \\
\hline & ha & $\%$ & ha & $\%$ & ha & $\%$ & ha & $\%$ & ha & $\%$ & ha & $\%$ & ha & $\%$ & ha & $\%$ & ha & $\%$ \\
\hline Herbaceous crops & 11 & 0.04 & 1,294 & 5.54 & 453 & 1.67 & 243 & 0.77 & 165 & 0.75 & 625 & 2.70 & 356 & 2.56 & 1,555 & 6.81 & 1,955 & 5.88 \\
\hline Fallow & - & - & 53 & 0.23 & - & - & 78 & 0.35 & - & - & - & - & 504 & 3.63 & 40 & 0.18 & 867 & 2.50 \\
\hline Woody crops & - & - & 29 & 0.12 & - & - & - & - & - & - & - & - & - & - & - & - & - & - \\
\hline Natural meadows & 2,520 & 9.57 & 413 & 1.77 & 948 & 3.50 & 654 & 2.08 & 1,534 & 6.98 & 82 & 0.35 & 1,388 & 10 & 1,400 & 6.19 & 1,334 & 4.01 \\
\hline Pastures & 10,257 & 38.97 & 9,305 & 39.81 & 19,109 & 70.63 & 5,565 & 17.71 & 2,874 & 13.08 & 8,669 & 37.18 & 3,625 & 26.14 & 7,166 & 31.68 & 10,535 & 31.68 \\
\hline Forests & 3,232 & 13.32 & 10,334 & 44.21 & 2,127 & 7.86 & 19,192 & 61.08 & 7,995 & 36.40 & 5,305 & 22.75 & 6,296 & 45.40 & 10,774 & 47.63 & 15,343 & 46.14 \\
\hline Open woods & 9,801 & 37.24 & 20 & 0.086 & 1,370 & 5.06 & 1,530 & 4.87 & 482 & 2.19 & - & - & 564 & 4.06 & 240 & 1.06 & 186 & 0.60 \\
\hline Brush woods & - & - & 1,583 & 6.77 & 445 & 1.64 & 2,798 & 8.90 & 1,802 & 8.20 & - & - & 547 & 3.94 & 991 & 4.38 & 2,644 & 7.95 \\
\hline Other areas & 488 & 1.85 & 354 & 1.51 & 2,603 & 9.62 & 1,360 & 4.33 & 7,110 & 32.37 & 8,636 & 37.03 & 579 & 4.17 & 453 & 2 & 387 & 1.16 \\
\hline Total area & 26,319 & & 23,375 & & 27,055 & & 31,420 & & 21,962 & & 23,317 & & 13,867 & & 22,619 & & 33,251 & \\
\hline
\end{tabular}

1957 indicate that cereal production occupied 74.5 percent of the cultivated land and grasslands only 15 percent; these statistics include the slopes which are used occasionally for crops. It is, therefore, a rural economy with agriculture based on cereals. This has led Puigdefabregas and Fillat (1986) to conclude that Pyrenean agriculture is, in fact, a Mediterranean agricultural system adapted to a mountain environment.

Secondly, the marked imbalance between summer pasturing resources and cultivable land, between livestock production and food supplies for the people, reached a maximum in the valleys that were devoted to stock raising, such as the Tena and Anso valleys (Balcells, 1983). This encouraged the development of transhumance, a system in which production in the mountains and on the plains are complementary. It enabled the maximum use of pasture in the valleys and sheep husbandry to become dominant in the economy. Figure 3 shows the significant linear correlation between summer pastures and livestock units in 1957. However, a correlation between the area under brushwood and woodland that can be used in winter and the number of livestock units is not significant. This indicates again the overriding role played by summer pastures; brushwoods and forest have little influence on the annual cycle because sheep can spend the winter on the plains of the Ebro Basin.

Nevertheless, cultivation and husbandry remained closely related. Fifty percent of the cultivated area was ac- tively cropped; half was fallow and used for grazing. Sheep were allowed access to cultivated lands after the harvest and remained near the villages before they moved to the Ebro Basin, thus providing organic fertilizer to the farmland. The interrelatioship between cereal crops and sheep has also been pointed out by Puigdefabregas (1980) and Chocarro et al. (1987).

It is concluded that the expansion of cultivation and the conversion of slopes for intermittent cropping was not only to feed a growing population but also to provide supplies of stubble that could be used to feed sheep in autumn (Puigdefabregas and Fillat, 1986). Spring and autumn were the crucial times for the supply of fodder to sheep; at the end of spring when sheep returned from the plains, they spent two or three weeks in the Prepyrenees in aborrales awaiting the opening of the summer pastures (Puigdefabregas and Balcells, 1966). Figure 4 indicates the traditional transhumance system in the Central Pyrenees.

The sheep that remained in the villages during winter made use of the stubble lands and brushwoods on low sunny slopes (bajantes) and also the leaves of oak, ash, and elm trees. The number of these sheep was very small compared with the migrating flocks of $1,000-1,500$ sheep. Some valleys could support up to 40,000 or 50,000 sheep. The Anso valley, for example, had some 49,040 sheep at the beginning of this century (Gorria Ipas, 1987).

Beef cattle, in contrast, were of minor importance. Cat-

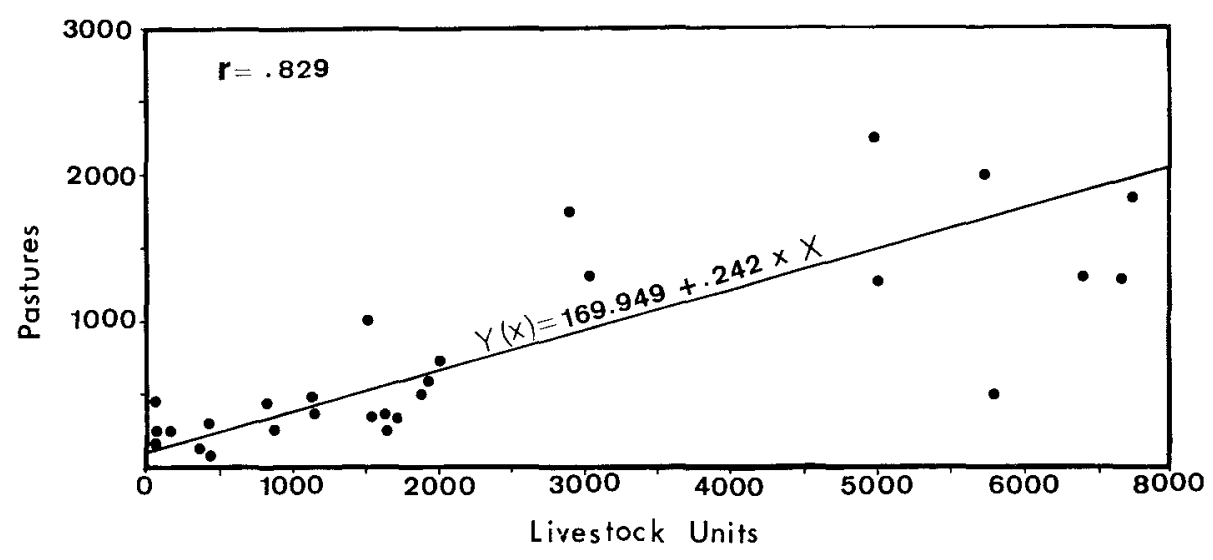

Figure 3. The relationship between the area of summer pastures and the number of livestock units. 


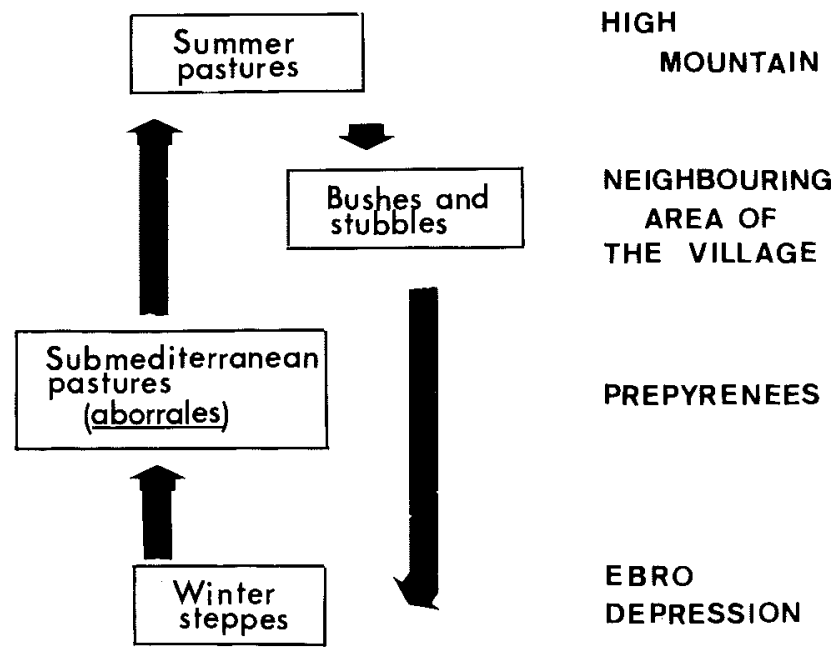

FIGURE 4. A model of the traditional pattern of transhumance in the Central Pyrenees.

the were usually kept by children or old people. They were taken to high mountain pastures in summer and in winter were kept near the village in boalares and cleared forest. Only in the severest weather were they kept in stalls, for the native breed of Pyrenean cow was adapted to the hardship of the environment. Occasionally the cattle herds exceeded 30 head and these larger herds would migrate to the Prepyrenean pardinas where there was rough but abundant pasture between November and May. This system provided meat at a very low cost, but there was also low production per livestock unit. Beef cattle are still kept today in the Anso and Hecho valleys; 42 percent of the cows in the Anso valley migrate although the migration period is much shorter than that of sheep. Thus, the Prepyrenean region played a double role in the traditional system: it sustained important beef herds during the winter and it provided temporary refuge for sheep flocks between the Ebro Basin and the summer pastures in the mountains.

The low importance of beef cattle explains why meadows were not developed in the most fertile areas (Kruger, 1939). Puigdefabregas and Fillat (1986) attribute their limited role to the lack of livestock in the valleys over a long period of time. Meadows were usually located on alluvial fans and colluvial slopes where they would be fertilized naturally by nutrients and silt inputs and where irrigation was possible. Figure 5 shows the distribution of meadows, cereal crops, and abandoned land in 1956 in relation to exposure, altitude, and gradient. Hay meadows were located at very low elevations, close to the villages and on more gentle gradients. Cereals had a wider altitudinal range and were grown even above $1,400 \mathrm{~m}$. The abandoned lands in 1956 correspond to plots with unfavorable features such as steep gradients and high altitude; they had been exploited under a nomadic system but were abandoned as the population declined.

The traditional system aimed to integrate all the elements of the ecosystem in order to reach a stable balance between population, resources, and livestock exploitation. The resources of the summer grazing pastures were the main factor in the development of herding and the complex land-use system in which the high valleys were complementary to the outer regions. Demographic pressure explains the expansion of agriculture to marginal areas. The prevalence of cereal cultivation is a consequence of both the need of food supplies for the people and the suitability of the cereal fields to sheep grazing. The different altitudinal belts and the variety of environmental factors underlie the very complex use of space and the relationships between the different landscape units within the land-use system.

\section{RECENT GHANGES IN LAND USE}

Spectacular changes have taken place, beginning in the $1950 \mathrm{~s}$ and escalating in the $1960 \mathrm{~s}$ and $1970 \mathrm{~s}$. A new demographic structure and decrease in population together with factors external to the Pyrenees led to the development of new systems of exploitation and important changes in land use.

A state of instability between the various elements of the ecosystem and the use of resources developed. Also maintenance and repair of the drainage systems and terrace walls were neglected as the supply of cheap and plentiful labor declined.

The great decrease in population destroyed the traditional social organization, and management systems more suited to the new demographic conditions were introduced. The most significant changes in the land use are as follows:

\section{Degrease in Cultivated Area}

Farming is now limited to the proximity of the villages, alluvial fans, or low fluvial terraces suitable for irrigation and mechanization where high rates of productivity are possible. Farming has been abandoned in villages located on perched flats and on slopes, even if terraced. Such sites are usually upstream from centers of population and may be difficult to reach, so that mechanization is not feasible; the growing season is also much shorter. These areas, never of great significance, have now become grazing lands.

The abandonment of cultivation in areas at lower and medium elevations is of greater importance. Their sunny exposures had overridden the topographical disadvantages and the land had been intensively farmed. The population pressure which reached its peak by the mid-nineteenth century (Anglada et al., 1980) led to the cultivation of these slopes but they can no longer be utilized and they have been transformed into extensive areas of waste land, invaded by brush and subject to erosion (Garcia-Ruiz and Puigdefabregas, 1982).

The decline in the areas of cultivation is not caused by the decrease in population. Rather, improved means of 

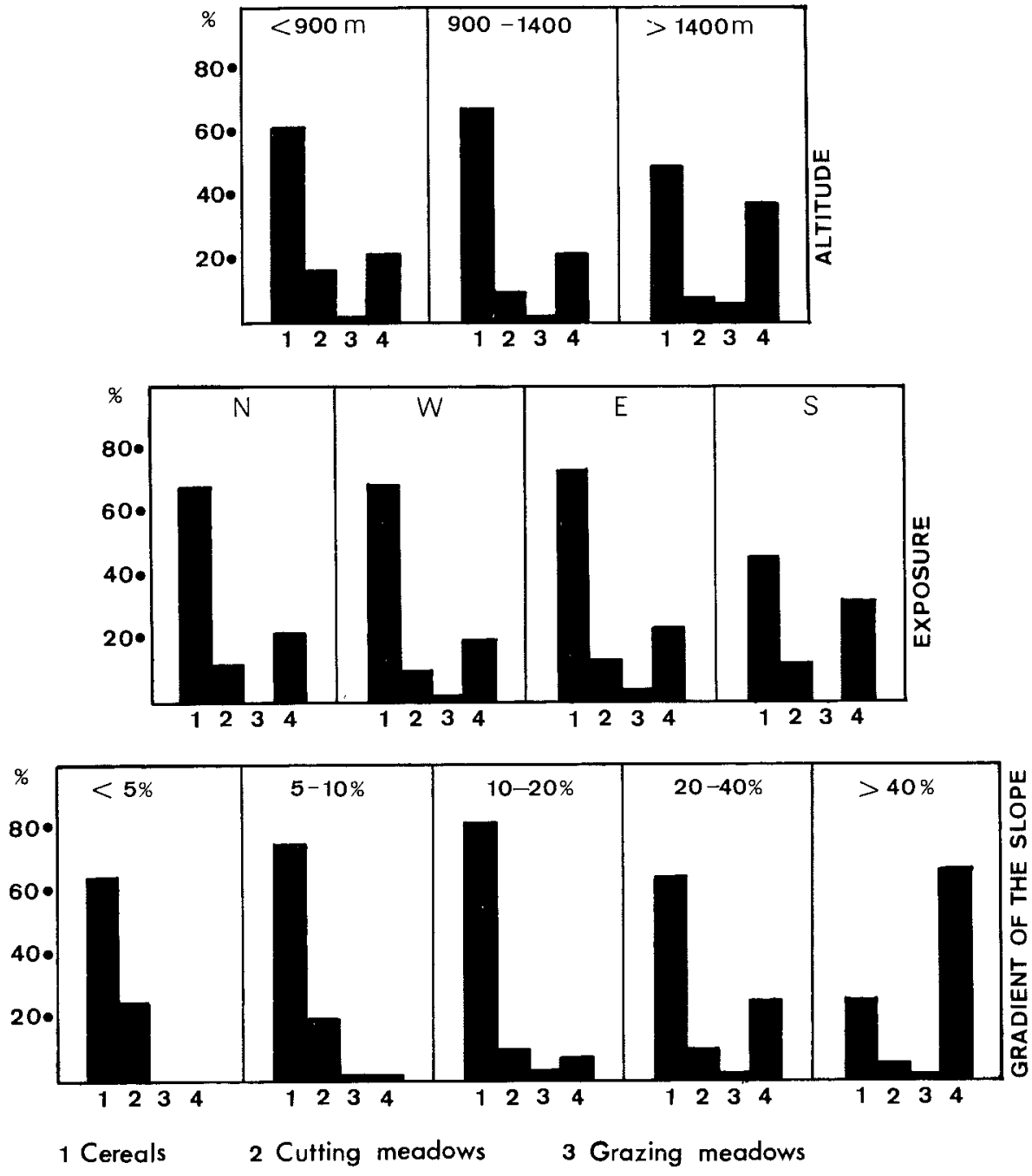

4 Abandoned fields
Figure 5. Types of land use in 1956, tabulated according to altitude, exposure, and gradient.

1. Cereals

2. Hay meadows

3. Pastures

4. Abandoned fields transport and the possibility of buying large quantities of fodder and cereal from other regions have made cultivation unprofitable. Soil erosion has also played a part in the decline of agriculture.

\section{The Decline in Cereal Produgtion and} InGREASE IN MEADOWS

Changes have taken place in the quality and quantity of land use. The traditional importance of cereals has practically disappeared, especially in the Central and Western Pyrenees. Cultivation lingers in the Navarre Pyrenees. In wide valleys, where mechanization is feasible, there are a few fields of barley for feeding cattle, but food supplies for the people must now be imported.

Figure 6 shows the changes in land between 1956 and 1981. Data were obtained from random sampling of air photographs. The present importance of hay fields on gentle slopes close to the villages and the great decline in the area under cereals are very evident; former cereal fields have now become hay meadows, grazing meadows, or have been abandoned.
These changes reflect, first, the economic disadvantages of cereal production in the mountain areas and, second, the evolution of the livestock management system. Table 3 shows the distribution of agricultural land in some Pyrenean valleys in 1957 and 1984. Only in the Hecho and Broto valleys is cereal production still important; it has disappeared in the Anso, Tena, and Benasque valleys. Among fodder crops, lucerne and temporary grasslands occupy a significant area; potatoes are important in the Western Pyrenees, along with some cereal cultivation; the reliable growth of hay in this wet mountain environment makes the production of cattle feed unnecessary.

\section{The Decline of Sheep and Expansion of Cattle Raising}

The decrease in the area of cereal cultivation and the increase in meadow land are related to changes in livestock management. The traditional predominance of sheep disappeared within a few years and has been partially replaced by a general increase in beef cattle. The underlying causes are complex. The basic problem lies in the changes that 
(A)

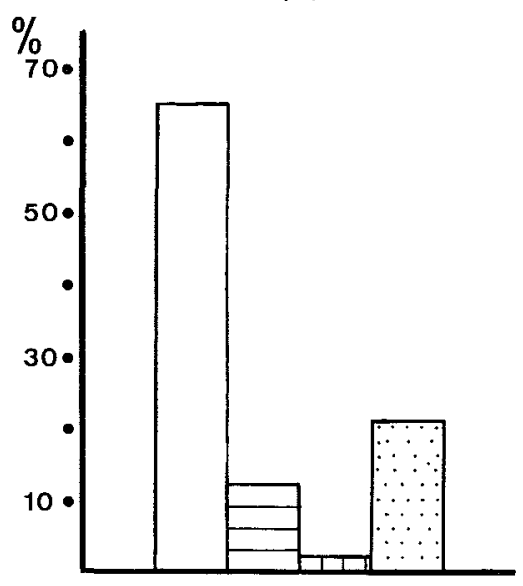

(B)

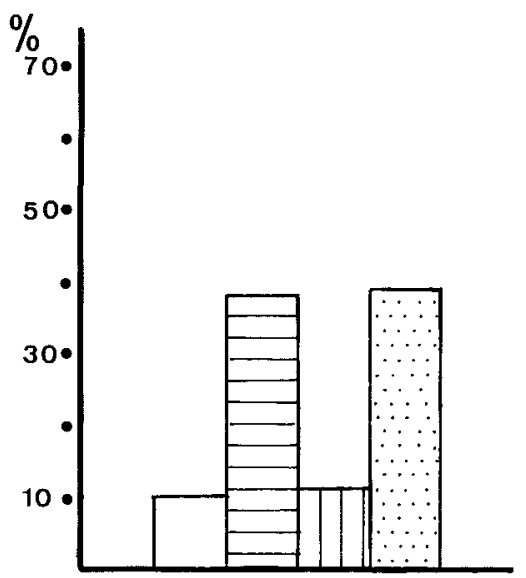

(c)

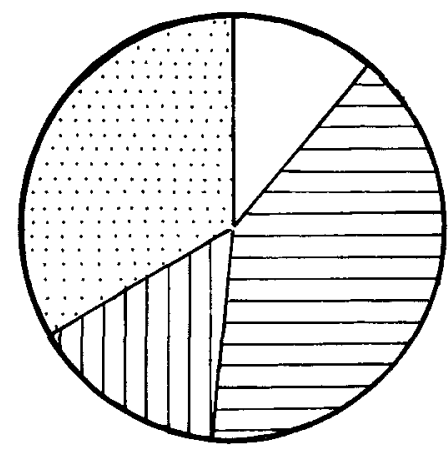

Figure 6. Land uses of the cultivated area in (A) 1957) and (B) 1981. The diagram below (C) shows the change of the old cereal fields (1957) into new land uses in 1981.
CEREALS

C CUTTING MEADOWS
WD GRAZING MEADOWS

$\therefore \quad$ ABANDONED FIELDS

TABLE 3

Various land uses in six Pyrenean valleys in 1957 and 1984 (in hectares)

\begin{tabular}{|c|c|c|c|c|c|c|c|c|c|c|c|c|c|}
\hline & & \multicolumn{2}{|c|}{ Anso } & \multicolumn{2}{|c|}{ Hecho } & \multicolumn{2}{|c|}{ Tena } & \multicolumn{2}{|c|}{ Broto } & \multicolumn{2}{|c|}{ Plan } & \multicolumn{2}{|c|}{ Benasque } \\
\hline & & 1957 & 1984 & 1957 & 1984 & 1957 & 1984 & 1957 & 1984 & 1957 & 1984 & 1957 & 1984 \\
\hline Cultivated area & & 318 & 11 & 1350 & 1376 & 753 & 453 & 974 & 321 & 391.6 & 105 & 151 & 625 \\
\hline Cereals & & 123.5 & - & 460 & 258 & 287.5 & 3 & 319 & 132 & 128.3 & 11 & 16 & - \\
\hline Vetch & & 5 & - & 2 & 9 & - & - & - & 7 & - & 4.5 & - & - \\
\hline Sugar beet & & - & - & - & - & - & - & 18 & - & - & - & - & - \\
\hline Potatoes & & 33.5 & 3 & 30 & 55 & 107 & 36 & 190 & 18 & 25.3 & 42 & 76 & - \\
\hline Fodder & & 19 & 6 & 105 & 914 & 182 & 408 & 68 & 79 & 105 & 100 & 11 & 622 \\
\hline Irrigated vegetables & & 2.33 & 2 & 23 & 29 & 13.4 & 6 & 1 & 7 & 8 & 7.5 & 3 & 3 \\
\hline Fruits & & - & - & - & 53 & - & - & - & - & - & - & - & - \\
\hline Vineyards & & - & - & 30 & 5 & - & - & - & - & - & - & - & - \\
\hline Fallow land & & 134.5 & - & 700 & 53 & 162.8 & - & 378 & 78 & 125 & - & 45 & - \\
\hline
\end{tabular}


TABLE 4

The number of livestock in six Pyrenean valleys in 1950 and 1982

\begin{tabular}{|c|c|c|c|c|c|c|c|c|}
\hline & \multicolumn{4}{|c|}{1950} & \multicolumn{4}{|c|}{1982} \\
\hline & Cows & Sheep & Goats & Horses & Cows & Sheep & Goats & Horses \\
\hline Anso & 500 & 28,200 & 1,505 & 303 & 793 & 10,160 & 170 & - \\
\hline Hecho & 503 & 8,245 & 1,367 & 499 & 1,147 & 7,480 & 570 & - \\
\hline Tena & 738 & 21,946 & 814 & 1,013 & 1,181 & 7,290 & 250 & - \\
\hline Broto & 767 & 6,140 & 578 & 504 & 1,578 & 2,600 & 190 & - \\
\hline Plan & 847 & 6,374 & 1,108 & 378 & 994 & 5,390 & 650 & - \\
\hline Benasque & 418 & 5,821 & 262 & 382 & 670 & 4,580 & 50 & - \\
\hline
\end{tabular}

have affected the transhumance system, beginning in the 1950 s.

Transhumance depends on two factors: a supply of cheap manpower for both the sheep breeding and agricultural activities so that the production unit may be divided during the winter; and the availability of nearby winter pastures so that costs are minimized and production is economically competitive. Both these factors have undergone change in recent years. Emigration has reduced the labor force and wide areas of the Ebro Basin have been transformed into irrigated fields; this forces the transhumant shepherds to leave the winter pastures prematurely in February. In addition, these pastures have become more and more expensive (Puigdefabregas and Balcells, 1966; Rinschede, 1972). The number of transhumant herders has declined and they are forced to chose between two alternatives: to give up sheep herding, the usual choice of the older sheep owners, or to reduce the size of the flock so that winter migration is no longer necessary. The latter choice has been adopted by many sheep farmers who practice a system of semi-stabling by which they alternatively import fodder and grow grass in their own fields. Thus, the huge flocks typical of the old transhumance system have disappeared and the few remaining flocks contain between 200 and 400 ewes (Garcia-Ruiz and Balcells, 1978).

The shift from an extensive system of migration to one where the animals are temporarily kept in stalls has of necessity caused a decline in the numbers of sheep in each valley (Table 4). The decrease since the beginning of this century amounts to 90 percent in some areas. Those villages that were traditionally devoted to sheep breeding have suffered most, as for example in the Roncal and Salazar valleys in the Navarre Pyrenees and Anso, Tena, Broto, Bielsa, and Benasque valleys in the Aragon Pyrenees. The problem also occurs in the Catalonian Pyrenees (Chapeau, 1986), where the decrease in cultivated area and the poor quality of winter pastures impede the adaptation of temporary stabling for animals. In the Anso valley the disappearance of transhumance has caused the social and economic collapse of one of the Pyrenean villages richest in livestock; the number of sheep was 45,517 in 1900; this was reduced to 11,553 in 1980, and it is still declining.

In contrast, beef cattle numbers have increased in every valley; this has taken the form of an increase in the number of cattle in each herd. In 1925, for instance, 74 percent of the herds in the Anso Valley had less than 10 cows; in 1980 , 88 percent of the herds numbered more than 20 head. Many sheep owners converted to cattle raising and the traditional proportion of sheep to cows was reversed. Figure 7 shows the changes in number of both types of animal in the Anso Valley between 1900 and 1985; the decline in sheep herding intensified after 1950 as the numbers of cattle increased. Sheep kept in stalls for certain periods require careful management while beef cattle need less supervision and are better suited to winter stabling. The shortage of manpower and the aging of the population encouraged the adoption of less demanding management techniques. Some village communities have been obliged to build stables to accommodate the cattle that remain in the valley in winter. This increase in beef cattle production has had important effects on land use.

The cultivation of cereals gave way to meadows in order to increase winter fodder production; those villages with

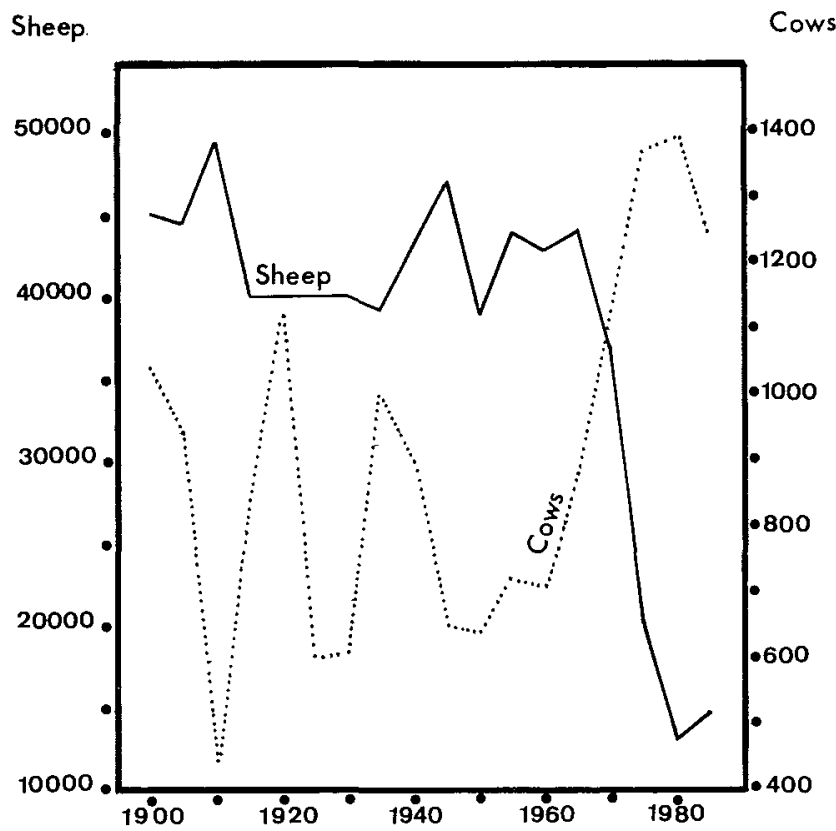

Figure 7. Changes in the number of livestock in the Anso Valley between 1900 and 1982 . 
A hillslope with small abandoned fields in the Bestue Valley; the fields are terraced and have a few trees.

The Tena Valley in Biescas; the lower part of the valley is now entirely cultivated, mainly with meadows and some cereals; in the middle ground of the photograph, an uncultivated alluvial fan encroaches from the left.

The Broto Valley, a Pleistocene glacial valley with meadows in the lowest areas; at the foot of the hillslopes there are small terraced fields, partially abandoned, and above is a mixed forest of oak and pine.
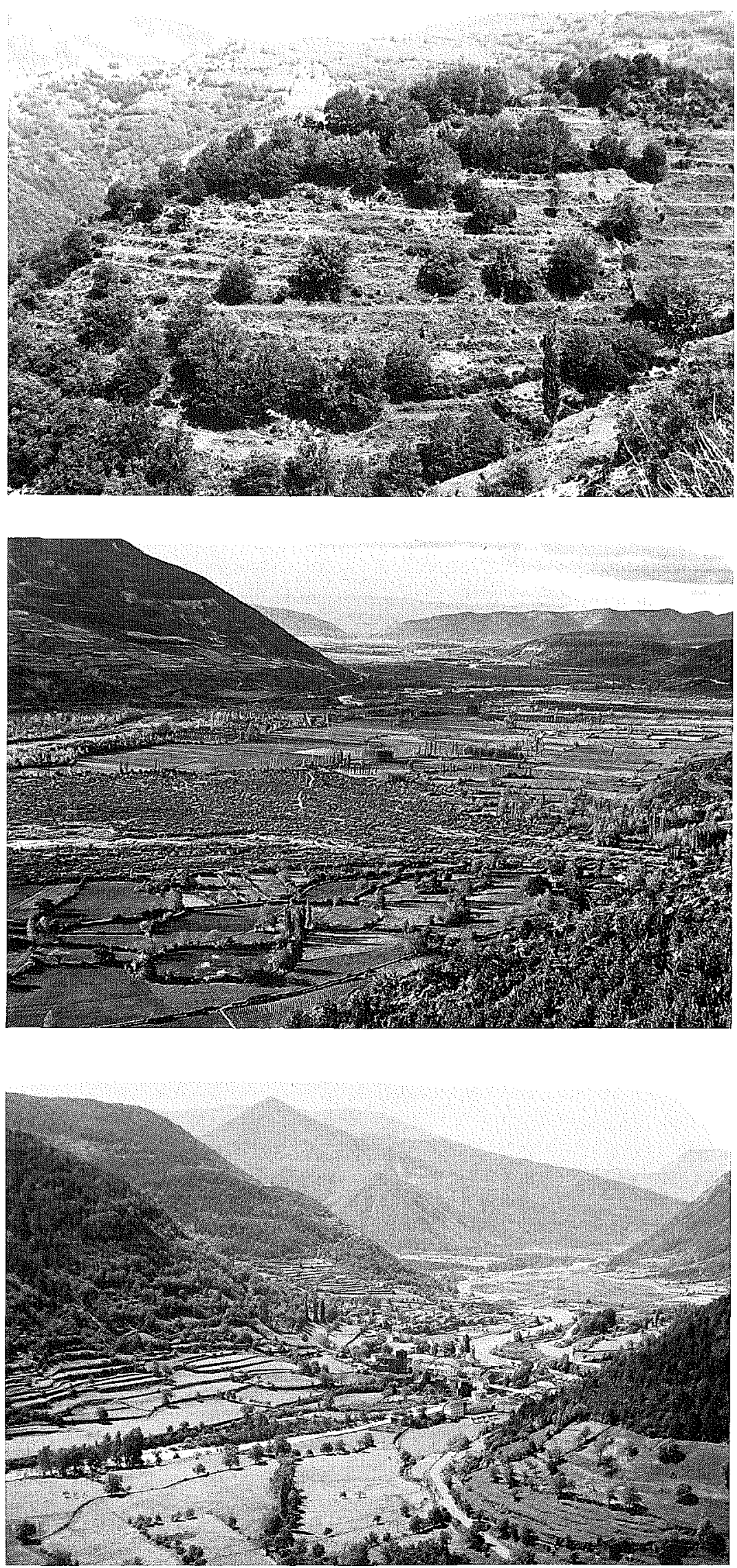
more cultivable land are better adapted to temporary stabling of animals. Valley bottoms are used intensively with heavy manuring and frequent harvesting (Montserrat $e t$ $a l ., 1984)$ and the intensity of use depends on the distance between the meadows and the village (Chocarro et al., 1987). The correlation between the meadow area per township and the number of cows is significant (Figure 8), particularly in the Western Pyrenees where cattle raising is still carried on with primitive methods. The correlation is, nevertheless, lower than expected, probably because farmers in the Central Pyrenees buy fodder from outside the region.

The large number of cows has a destabilizing effect on summer pastures. Only those mountain areas in wide glaciated valleys are well adapted to beef cattle for they are usually wet and have gentle slopes. Such pastures are now overexploited and the increase of unpalatable plant species with little fodder value is causing a decline in the quality of the pastures (Ferrer et al., 1986). This contrasts with the abandonment of many other pastures that were suitable for sheep but are now unused (Balcells, 1983). The pastures have a tendency to decline at lower altitudes because once grazing is reduced there is a development of woody vegetation (Montserrat, 1964).

The change from the traditional land-use system has two major results: first, many of the herbaceous resources above timberline are no longer used as there is no livestock there; second, the breeding of beef cattle has resulted in an intensification of production which is further reinforced by imports of fodder. Thus, we conclude that beef cattle production under a regime of part-time stabling is extensive in terms of the labor requirements but highly intensive in terms of the spatial factors because production is concentrated in very limited areas. In contrast, sheep breeding is extensive in land use but is intensive in manpower requirements. Therefore, beef cattle are better adapted to the present social and economic circumstances because the present transport facilities allow the concentration of production in small areas and the subsequent abandonment of the more marginal land. This abandonment is evident when the area of summer pastures in 1982 is correlated with the number of cattle units. The results $(r=0.33)$ indicate that there is no relation between the variables. Earlier, in 1957, the correlation was positive and significant. There is also a positive correlation between the area of bajantes (winter grazing grounds) and the number of cattle raising units in each township. This indicates that winter pasture resources have a control effect on present cattle development but summer pastures do not. In the traditional system, the summer grazing area was the significant factor that controlled the specific importance of cattle in each township,

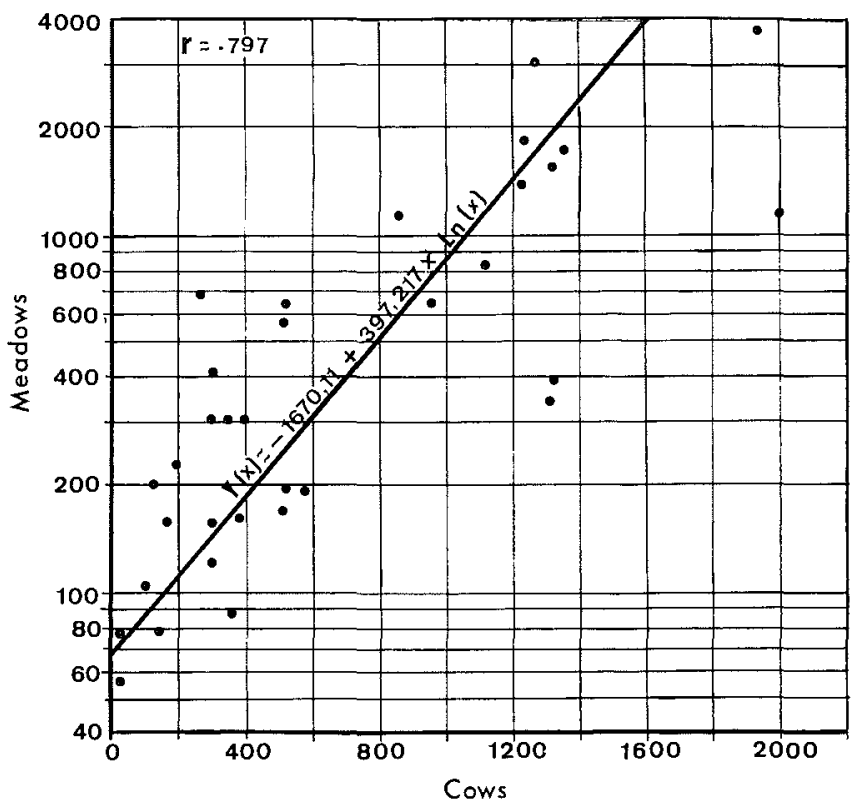

Figure 8. The correlation between the area of meadows (in hectares) and the number of cows in 1982.

given that winter feeding was provided by seasonal migration.

This recent intensification has a counterpart in the increase of dairy cattle. By the beginning of this century, the production of milk had been introduced into some areas of the Catalonian Pyrenees and dairy cooperatives had been formed. At the same time dairy cattle had become somewhat important in the Western Pyrenees, stimulated by the proximity of urban centers and the availability of suitable grasslands. However, in the Central Pyrenees dairying was introduced only very recently and to a much lesser degree because of the distance from large consumer markets and the difficulties of transportation. During the last few years several dairy companies have been collecting milk produced in certain valleys on a daily basis. These businesses are locally supported and milk undergoes primary treatment at small collecting centers. This local industry has encouraged production in nearby villages and dairy cattle are increasing in number, but it is a slow, very selective process centered on fertile areas where there is better access to population centers, such as Campo, Biescas, and Broto (Manrique, 1976); this trend will no doubt continue. It also leads to abandonment of the rest of the land.

\section{LAND-USE CHANGES RESULTING FROM EXTERNAL FACTORS}

The land-use system in mountain lands is complex and the introduction of non-rural activities to compete with farming may cause severe problems. In the Pyrenees, such competition arises from the introduction of tourism and the building of dams.

The significant increase in winter and summer tourism during the 1960s had a two-fold effect. First, land in the most favored locations was taken over for the construction of resort centers and recreational activities (Balcells, 1983, 1984). These were the areas on which winter food production had depended.

Second, the development of tourism in some villages led 
to slope abandonment and a decrease in cattle raising. In many cases, cattle farmers became involved in the service sector-hotels, commerce, and retailing. Stock breeding activities were relegated to second priority and livestock numbers were not maintained or increased. The raising of beef cattle is based on summer pastures, hay from meadows, and fodder bought outside the area, but winter grazing was minimal and hillslope abandonment was accentuated. It is easy to understand how lack of time affects new merchant farmers who can no longer maintain flocks; the second generation now is no longer interested in cattle raising and devotes all its efforts to commerce, hotel management, and working in the winter resorts. It is curious that the correlation between hotel vacancies and cattle production units per township is significant and negative; that is to say, the most highly developed tourist areas tend to be the least involved in livestock breeding a fact which emphasizes the incompatibility between the two interests.
Dam building has different effects, ones that are probably more serious. Certain needs, such as water regulation for irrigating the plains and hydroelectricity, force dam construction and the drowning of villages and fertile valley basins. Reservoirs are located in relatively wide valleys (with very high agricultural value) that narrow at the point where the river cuts through a thick band of limestone. Dam construction destabilizes the land-use system with the loss of the best lands where winter food reserves were grown (Garcia-Ruiz, 1977). This has a negative impact in a mountain region where cattle raising requires a balance between highly productive meadows and extensive pastures (Anglada et al., 1980). The building of large reservoirs prevents use of the valley bottoms and this affects land use throughout the area. The Tena Valley is the best example of a valley affected by dam building and tourism.

\section{CONCLUSIONS}

The Pyrenees may be thought of as a heterogeneous landscape that until recently has maintained a complex spatial organization based on an equally complex social organization (Esteva-Fabregat, 1971; Pujadas and Comas, 1975). That system was controlled by two factors: the existence of an extensive area of highly productive summer pastures with a short growing season and the need to provide food for a population that exerted increasingly strong pressure on the land during the nineteenth century. The first factor led to the traditional importance of sheep breeding and to the seasonal migration to make use of both winter and summer patures. The second factor explains the extension of cropping areas, mainly for cereals, even onto land with unfavorable topographic conditions.

Beginning in the mid-1950s and escalating from then onward, the traditional land-use system has been destabilized by a number of factors: population reduction and aging undermined the traditional social organization; better communications allowed the import of more competitive products, such as cereals, from the plains; and tourism and other urban interests attracted a significant part of the labor force toward the tertiary sector and the development of non-rural land uses.

In the context of models of mountain development, we conclude that the present land-use system in the Pyrenees can be defined (i) by an increasing lack of coordination

\section{REFERENCES}

Anglada, S., Balcells, E., Creus, J., Garcia-Ruiz, J. M., and Puigdefabregas, J., 1980: La vida rural en la montaña española. Instituto de Estudios Pirenaicos, 113 pp., Jaca.

Balcells, E., 1983: Evolución socioeconómica reciente de tres comunidades comarcales pirenaicas y destino actual de las superficies más productivas de su territorio. Cuadernos de Investigación Geográfica, 9: 41-82, Logroño. among the different units integrating the valley system; (ii) by the end of the role of summer pastures in the exploitation pattern, as the number of cattle is now limited by available winter resources; and (iii) by the reduction in area of well-managed land.

However, this process has not yet been completed throughout the Pyrenees; intensification has reached its peak in Catalonian valleys, such as Alto Segre (Balcells, 1983 , 1984), where dairy farming is now prominent. In other valleys a balance between dairying in valley bottoms and beef cattle on the slopes has been achieved. Some rich agricultural valleys have adapted to the new socioeconomic conditions by replacing nomadic sheep with beef cattle which are kept in stalls for part of the year. And some valleys, such as the Anso Valley, were unable to adapt to the new conditions and cattle raising collapsed completely. This is also the case in valleys that have been affected by tourism and dam construction.

To conclude, those villages where stock raising was most important in the past have suffered the most severe destabilization, which is partially mitigated by the inputs of energy from outside. Those villages that were able to maintain an adequate balance between extensive pastures (above timberline) and intensive resources (in valley bottoms) have been able to adjust to change.

\footnotetext{
, 1984: Exemples d'utilisation des espaces plus fertiles dans les finages des Pyrénées Centrales. Face à l'évolution des différents secteurs de production. IGU Subcom. Rural life and the exploitation of natural resources in highlands and high latitude zones. II Symp. Barcelona-Pyrenees. 105-112, Barcelona.

Chapeau, G., 1986: La mise en valeur d'une région de montagne: Le Val d'Aran. Revue de Comminges, 98: 1-37.
} 
Chocarro, C., Fillat, F., Garcia, A., and Miranda, P., 1987 Prados del Pirineo Central: composición florística y calidad. Pirineos, 129: 7-33.

Creus, J., 1978: La transición climática altoaragonesa. Estudios Geográficos, 153: 495-518, Madrid.

Daumas, M., 1976: La vie rurale dans le Haut Aragon Oriental. Instituto de Geografía Aplicada, 774 pp., Madrid.

, 1986: La redistribution géographique de la population dans les hautres vallées montagnardes: l'exemple du Val de Benasque. Revue de Géographie Alpine LXXIV (1-2): 189196.

Esteva-Fabregat, C., 1971: Para una teoría de la aculturación en el Alto Aragón. Ethnica, 2: 9-78, Barcelona.

Ferrer, Manrique, Amella, and Ocaña, 1986: Some remarks on farming prospects and dynamics in the Aragonese Pyrenees (Spain). Regional Conference on Mediterranean Countries. I.G.U. Jaca-Barcelona.

Garcia-Ruiz, J. M., 1976: Modos de vida y niveles de renta en el Prepirineo del Alto Aragón Occidental. Instituto de Estudios Pirenaicos, 272 pp., Jaca. , 1977: Grandes embalses y desorganización del espacio. El ejemplo del Alto Aragón. Cuadernos de Investigación Geográfica, 3: 31-46, Logroño.

-, 1988: La evolución de la agricultura de montaña y sus efectos sobre la dinámica del paisaje. Revista de Estudios AgroSociales, 146: 7-37.

Garcia-Ruiz, J. M. and Barcells, E., 1978: Tendencias actuales de la ganadería en el Alto Aragón. Estudios Geográficos, 153: 519-538, Madrid.

Garcia-Ruiz, J. M., Lasanta, T., and Sobron, I., 1985: Estudio comparativo de la evolución geomorfológica de campos abandonados y àreas repobladas de la cuenca del Jubera. Comunidad Autónoma de la Rioja, Informe, 345 pp., Longroño.

Garcia-Ruiz, J. M. and Puigdefabregas, J, 1982: Formas de erosión en el flysch eoceno surpirenaico. Cuadernos de Investigación Geográfica, 8: 85-130, Logroño.

Gomez, D. and Fillat, F., 1984: Utilisation du frêne comme arbre fourrager dans les Pyrénées du Huesca. Ecologie des milieux montagnards et de haute altitude. Documents d'Ecologie Pyrénéenne, III-IV: 481-489, Gabas (France).

Gorria Ipas, A. J., 1987: Evolucion y crisis demografica de la organizacion social. El valle de Anso. Inst. de Estudios Altoargoneses, Huesca, 216 pp.

Kruger, F:, 1939: Die Hochpyrenäen, G. Ländliche Arbeit. Band II. Mansischer Gildeuverlag, 500 pp., Hansburg.
Liso Puente, M, and Ascaso Liria, A., 1969: Introducción al estudio de la evapotranspiración y clasificación climática de la cuenca del Ebro. Anales de la Estación Experimental de Aula Dei, 10 (1-2): 505 pp., Zaragoza.

Manrique, E., 1976: Comercialización del ganado y de los productos ganaderos en los valles de Tena y Canfranc (1972-73). Anales de la Facultad de Veterinaria, pp. 541-580, Zaragoza.

Millones, J., 1982: Patterns of land use and associated environmental problems of the Central Andes. Mountain Research and Development, 2 (1): 49-61

Montserrat, P., 1964: Ecología del pasto. Publ. Centro Pir. Biol. Exp., 1(2): 1-68, Jaca.

Montserrat, P., Gomez, D., and Montserrat, G., 1984: Phytosociologie et dynamique prairiales dans quelques cultures pyrénéennes intégrées à leur paysage. Documents d'Ecologie Pyrénéenne, 3-4: 471-479, Gabas.

Puigdefabregas, J., 1980: Explotación del Alto Aragón por la población humana. Introducción general y explotación de los productos primarios. Actas del I Congreso Español de Antropología, pp. 52-66, Barcelona.

P. 1981: El Pinar altoaragonés de Pinus sylvestris. Estructura y producción primaria neta. Tesis Doctoral. Universidad de Navarra.

Puigdefabregas, J. and Balcells, E., 1966: Resumen sobre el régimen de explotación ovina trashumante en el Alto Aragón, especialmente en el Valle de Ansó. Publ. Centr. Pir. Biol. Exp., 1 (6): 1-18, Jaca.

— 1970 : Relaciones entre la organización social y la explotación del territorio en el Valle de El Roncal (Navarra oriental). Pirineos, 98: 53-89, Jaca.

Puigdefabregas, J. and Fillat, F., 1986: Ecological adaptation of traditional land uses in the Spanish Pyrenees. Mountain Research and Development, 6 (1): 63-72.

Pujadas, J. J. and Comas, D., 1975: La casa en el proceso de combio del Pirineo Aragonés. Cuadernos de Investigación Geográfica, 1 (2): 51-62, Logroño.

Rinschede, G., 1972: Die Transhumance in den frauzösischen Westalpen und in den Pyrenäen. Doct. thesis. Munster Westf. Univ. (Geogr.). 524 pp.

Violant, R., 1949: El Pirineo español. Ed. Plus Ultra. Madrid. $675 \mathrm{pp}$. 